\title{
Bir Üniversite Hastanesinde Kan Kültürlerinden İzole Edilen Bakterilerin Kümülatif Antibiyogram Sonuçları
}

\section{Cumulative Antibiogram Results of Bacteria Isolated from Blood Cultures in a University Hospital}

Lütfiye Öksüz ${ }^{1}$, Zerrin Aktaş ${ }^{1}$

öz

Amaç: Bu çalıșmada, kan kültürlerinden izole edilen bakterilerin kümülatif antimikrobiyal verileri araștırılmıș ve klinisyenlerin ampirik tedavi seçimine katkıda bulunulması amaçlanmıștır Gereç ve Yöntem: Çalışmaya Ocak 2018-Mayıs2019 arasında çalıșlan kan kültürleri dahil edilmiștir. Sadece izolat sayısı $>30$ olan bakteriler değerlendirilmiștir. Her hasta için ilk izolat çalışmaya dahil edilmiştir. Ampirik tedavi için kümülatif antibiyotik duyarlılık sınırı >\%90 olarak kabul edilmiştir.

Bulgular: Metisiline dirençli Staphylococcus aureus izolatlarında ampirik tedavi için en uygun antibiyotiklerin vankomisin, teikoplanin ve linezolid olduğu; metisiline duyarlı $S$. aureus izolatlarında bu antibiyotiklere ek olarak kotrimoksazol ve tetrasiklin seçeneklerinin olduğu bulunmuştur. Enterococcus faecalis izolatlarında vankomisin, teikoplanin ve linezolide ek olarak ampisilin ve yüksek düzey gentamisinin ampirik tedaviye uygun olduğu bulunurken, Enterococcus faecium izolatlarında tek ampirik tedavi seçeneğinin linezolid olduğu belirlenmiștir. Genișlemiș spektrumlu beta laktamaz olușturmayan grupta karbapenemlere ek olarak 3. ve 4. kuşak sefalosporinler, aminoglikozidler ve piperasilin+tazobaktam ampirik tedavi için uygun olmasina rağmen, GSBL oluşturan Escherichia coli izolatlarında sadece karbapenem grubu antibiyotikler ampirik tedavi için uygun bulunmustur. GSBL pozitif Klebsiella pneumoniae için ampirik tedavi seçeneği olmadığı ve bu grupta karbapenem direncinin \% 50’ye ulaştığı bulunmuştur. GSBL negatif izolatlarda 3. ve 4. kuşak sefalosporinler, karbapenemler, aminoglikozidler ve siprofloksasinin ampirik tedavi için uygun olduğu bulunmuştur.

Sonuç: Çalışmamızda elde edilen yüksek direnç oranları nedeniyle, düzenli sürveyans takibinin yapılması gerekmektedir. Karbapenemleri de kapsayan çoğul dirençli mikroorganizmalar için antibiyotik kombinasyonlarının etkinliğini test eden çalışmalara ihtiyaç vardır.

Anahtar Kelimeler: Kan kültürü, kümülatif antibiyogram, antimikrobiyal direnç

\section{ABSTRACT}

Objective: This study investigated the cumulative antimicrobial data of bacteria isolated from blood cultures and aimed to contributing to clinicians' empirical treatment selection.

Material and Methods: The study included blood cultures studied between January 2018 and

1 İstanbul Üniversitesi, İstanbul Tip Fakültesi, Tibbi Mikrobiyoloji Anabilim Dalı, İstanbul, Türkiye

ORCID: L.Ö. 0000-0002-6722-141X; Z.A. 0000-0002-5998-0440

Sorumlu yazar/Corresponding author: Lütfiye Öksüz,

İstanbul Üniversitesi, İstanbul Tip Fakültesi, Tibbi Mikrobiyoloji Anabilim Dal, İstanbul, Türkiye E-posta: oksuzl@istanbul.edu.tr

Başvuru/Submitted: 05.05.2020 Kabul/Accepted: 16.06.2020

Atıf/Citation: Oksuz L, Aktas Z. Cumulative Antibiogram Results of Bacteria Isolated from Blood Cultures in a University Hospital. Sağlık Bilimlerinde İleri Araștırmalar Dergisi 2020; 3(2): 35-44. https://doi.org/10.26650/JARHS2020-732729
May 2019. Only bacteria species that have 30 or more isolates were evaluated. Only the first isolate for each patient was included in the study. The cumulative antibiotic susceptibility limit for empirical treatment was $>90 \%$.

Results: The most appropriate antibiotics for empirical treatment in methicillin-resistant Staphylococcus aureus isolates were vancomycin, teicoplanin and linezolid. Co-trimoxazole and tetracycline options in addition to vancomycin, teicoplanin and linezolid were suitable for therapy in methicillin-sensitive $S$. aureus isolates. Ampicillin and high level-gentamicin alongside vancomycin, teicoplanin and linezolid were found to be appropriate for empirical treatment in Enterococcus faecalis isolates, while linezolid was the only option in Enterococcus faecium isolates. Although cephalosporins, aminoglycosides and piperacillin tazobactam as well as carbapenems were suitable for empiric therapy in the ESBL-negative group, only carbapenems were found suitable for empirical treatment in Escherichia coli isolates producing extended-spectrum betalactamase. There was no empirical treatment option for ESBL positive Klebsiella pneumoniae. Carbapenem resistance of these bacteria was found to reach 50\%. Third and 4 th generation cephalosporins, carbapenems, aminoglycosides and ciprofloxacin were appropriate for empirical treatment in ESBL negative K. pneumoniae isolates.

Conclusion: Due to the high resistance rates in our study, regular surveillance monitoring should be performed. Studies are needed to test the efficacy of antibiotic combinations for multi-resistant organisms, including carbapenem-resistant bacteria.

Keywords: Blood culture, cumulative antibiogram, antimicrobial resistance 


\section{GİRIŞ}

Antibiyotik direnci oranları bölgelere ve zamana göre değişkenlik gösterdiğinden klinik olarak önemli mikroorganizmalara karşı ampirik tedavi seçeneklerinin belirlenebilmesi, morbidite ve mortalitenin azaltılabilmesi için antibiyotik direncinin rutin olarak takip edilmesi gerekir. Antibiyotik direnci takibinde, ampirik antimikrobiyal tedavinin seçiminde klinisyenlere fayda sağlamak amacıyla sıklıkla kümülatif (toplu) antibiyogramlar kullanılmaktadır (1). Güvenilir kümülatif antibiyogram sonuçlarının, hastaya ait kültür sonuçlarının henüz mevcut olmadığı durumlarda, hem etkisiz antibiyotik seçimini, hem de geniş spektrumlu antibiyotiklerin aşırı reçete edilmesini önlemeye yardımcı olabileceği bildirilmiştir (2). Kümülatif antibiyogram verileriyle birlikte kısıtlı antibiyogramin da uygulanmasıyla uygun ampirik tedavi rejimi seçilebilmekte ve antibiyotik direnciyle mücadele için uygun politikalar oluşturulabilmektedir.

$\mathrm{Bu}$ çalışmanın amacı, hastanemizde kan dolaşımı enfeksiyonlarından izole edilen bakterilerin kümülatif antimikrobiyal duyarlılık verilerini irdeleyerek klinisyenlerin başlangıç ampirik tedavi seçimine ve antibiyotik yönetimi politikalarına katkıda bulunmaktır.

\section{GEREÇ VE YÖNTEM}

Bu çalışmada, Ocak 2018-Mayıs 2019 tarihleri arasındaki 16 aylık süreçte, kan kültürlerinden izole edilen belli bakterilerin antibiyotiklere duyarlılıkları değerlendirilmiştir. Hastanemizin çeşitli kliniklerinden Tibbi Mikrobiyoloji laboratuvarına gönderilen kan kültürü örnekleri, BACTEC FX (Beckton Dickinson-ABD) otomatik kan kültürü sisteminde beş gün süreyle inkübe edilmiştir. Pozitif sinyal veren şişelerden izole edilen mikroorganizmaların tanımlanması, konvansiyonel yöntemler ve gerektiğinde otomatik identifikasyon sistemiyle (Phoenix 100, Beckton Dickinson-ABD), antibiyotik duyarlılık testleri disk difüzyon ve bazı antibiyotikler için gradiyent test yöntemiyle yapılmış ve Clinical and Laboratory Standards Institute 2017 (3) önerilerine uygun olarak değerlendirilmiştir. Kümülatif antibiyogram verileri CLSI M39-A4 önerileri kullanılarak değerlendirilmiştir $(1,4)$. Hastalara ait demografik veriler hastane otomasyon sisteminden alınmıştır. Kümülatif antibiyogram kurallarına uygun olarak izolat sayısı $>30$ olan bakteri türleri değerlendirmeye alınmıștır (1). Her hasta için ilk izolata ait duyarlılık sonuçları dahil edilmiștir. Çalıșmada sadece rutin olarak test edilen antibiyotiklerin duyarlılık sonuçları değerlendirmeye alınmıştır. Ampirik tedavi için kümülatif antibiyotik duyarlılık sınırı > \% 90 olarak kabul edilmiştir. Çoğul direnç, sefalosporinlere, aminoglikozidlere ve florokinolonlara direnç olarak ele alınmıştır (4). Çalışma, Helsinki Bildirgesi'ne uygun olarak gerçekleştirilmiştir.

\section{BULGULAR}

Kan kültürlerinden mikroorganizma izole edilen hastaların 334'ünün $(\% 36,9)$ çeşitli kliniklerde (\%19,7'si yoğun bakım ünitesinde) yattığı, kalan hastaların poliklinik hastası olduğu ve tüm hastaların 338 'inin $(\% 37,5)<18$ yaş olduğu belirlenmiștir.

On altı aylık süreçte kan kültürlerinden toplam 929 adet mikroorganizma izole edilmiştir (Tablo 1). Gram pozitif bakteriler arasında, en yaygin patojenin Staphylococcus aureus ( $\mathrm{n}=94)$, ikinci en sik izole edilen patojenin Enterococcus spp $(\mathrm{n}=30)$ olduğu gözlenmiștir. S. aureus izolatlarının \% 38,3'ünün metisiline dirençli $S$. aureus (MRSA) olduğu ve bu grupta ampirik tedavi için en uygun antibiyotiklerin vankomisin, teikoplanin ve linezolid olduğu; metisiline duyarlı S. aureus (MSSA) izolatlarında bu antibiyotiklere ilave olarak kotrimoksazol ve tetrasiklin seçeneklerinin olduğu bulunmuştur. Tüm Enterococcus spp izolatlarında vankomisin, teikoplanin ve linezolidin en uygun ampirik tedavi seçenekleri olduğu bulunmuştur. Tür düzeyinde incelendiğinde, E. faecalis izolatlarında ampisilin, vankomisin, teikoplanin, linezolid ve yüksek düzey gentamisinin ampirik tedaviye uygun olduğu bulunurken, E.faecium izolatlarında tek ampirik tedavi seçeneğinin linezolid olduğu belirlenmiştir (Tablo 2).

Gram negatif bakteriler arasında en sik izole edilen patojenin Escherichia coli ( $\mathrm{n}=112)$ ve ikinci patojenin Klebsiella pneumoniae $(\mathrm{n}=67)$ olduğu saptanmıştır. Genişlemiş spektrumlu beta laktamaz (GSBL) oluşturan E. coli izolatlarında sadece karbapenem 
Tablo 1. Kan kültürlerinden izole edilen antibiyotikler ve oranları

\begin{tabular}{|c|c|c|c|c|c|}
\hline Gram pozitif bakteriler & Sayı (n) & Oran (\%) & Gram negatif bakteriler & Sayı (n) & Oran (\%) \\
\hline Enterococcus spp & 30 & 4,5 & Escherichia coli & 112 & 43,2 \\
\hline Enterococcus faecalis & 9 & & Klebsiella pneumoniae & 66 & 25,5 \\
\hline Enterococcus faecium & 21 & & Klebsiella oxytoca & 3 & 1,1 \\
\hline Staphylococcus aureus & 93 & 14 & Enterobacter spp & 15 & 5,8 \\
\hline Metisiline dirençli S. aureus & 35 & 37,6 & Serratia marcescens & 9 & 3,5 \\
\hline Metisiline duyarlı S. aureus & 58 & 62,4 & Salmonella spp & 2 & 0,8 \\
\hline Koagülaz negatif stafilokok & 443 & 66,7 & Aeromonas spp & 1 & 0,4 \\
\hline Metisiline dirençli KNS & 220 & & Gram negatif çomak & 2 & 0,8 \\
\hline Metisiline duyarlı KNS & 106 & & Proteus mirabilis & 1 & 0,4 \\
\hline Streptococcus pneumoniae & 17 & 2,6 & Pseudomonas spp & 21 & 8,1 \\
\hline Viridans streptokok & 12 & 1,8 & Acinetobacter spp & 11 & 4,2 \\
\hline S. pyogenes & 1 & 0,15 & Stenotrophomonas maltophilia & 1 & 0,4 \\
\hline S. agalactiae & 1 & 0,15 & Nonferm Gram neg çom & 5 & 1,9 \\
\hline Corynebacterium spp & 24 & 3,6 & Haemophilus influenzae & 1 & 0,4 \\
\hline Leuconostoc spp & 1 & 0,15 & Brucella spp & 3 & 1,1 \\
\hline Alfa hemolitik streptokok & 29 & 4,4 & Neisseria $s p p$ & 1 & 0,4 \\
\hline Bacillus spp & 5 & 0,7 & Sphingomonas paucimobilis & 1 & 0,4 \\
\hline Beta hemolitik streptokok & 5 & 0,7 & Brevundimonas vesicularis & 1 & 0,4 \\
\hline Listeria monocytogenes & 1 & 0,15 & Burkholderia spp & 1 & 0,4 \\
\hline Streptococcus gordonii & 1 & 0,15 & Chryseobacterium indologenes & 1 & 0,4 \\
\hline Dermacoccus spp & 1 & 0,15 & & & \\
\hline Toplam & 664 & 99,9 & Toplam & 259 & 100 \\
\hline \multicolumn{6}{|l|}{ Anaerop bakteriler } \\
\hline Bacteroides fragilis grubu & 1 & & & & \\
\hline Prevotella spp & 1 & & & & \\
\hline Anaerop Gram pozitif kok & 1 & & & & \\
\hline \multicolumn{6}{|l|}{ Mantarlar } \\
\hline Candida spp & 2 & & & & \\
\hline Rhizopus radiobacter & 1 & & & & \\
\hline Genel Toplam & 929 & & & & \\
\hline
\end{tabular}

Tablo 2. Gram pozitif koklarda antibiyotik duyarlılık yüzdeleri

\begin{tabular}{|c|c|c|c|c|c|c|c|c|c|c|c|}
\hline Duyarlılık \% & $\begin{array}{l}\text { İzolat } \\
\text { sayıs1 }\end{array}$ & PG & AMP & VA & TEC & $\mathbf{E}$ & $\mathrm{CC}$ & SXT & TE & LZD & GN 120 \\
\hline Enterococcus spp & 30 & & 63,3 & 90 & 90 & & & & & 100 & 83,3 \\
\hline E. faecium (\%22 VRE) & $9^{*}$ & & 11,1 & 77,7 & 77,7 & & & & & 100 & 66,6 \\
\hline E. faecalis (\%4,7 VRE) & $21^{\star}$ & & 90,4 & 95,2 & 95,2 & & & & & 100 & 90,4 \\
\hline $\begin{array}{l}\text { Staphylococcus } \\
\text { aureus }\end{array}$ & 94 & 15,9 & - & 100 & 100 & 60,6 & 70,2 & $\begin{array}{c}\mathbf{9 1 , 5} \\
(\mathrm{n}=94)\end{array}$ & 85,1 & 100 & - \\
\hline $\begin{array}{l}\text { Metisiline dirençli } \\
\text { S. aureus }\end{array}$ & 36 & 0 & - & 100 & 100 & 33,3 & 41,7 & $85,2(\mathrm{n}=27)$ & 75,0 & 100 & - \\
\hline $\begin{array}{l}\text { Metisiline duyarlı } \\
\text { S. aureus }\end{array}$ & 58 & 25,8 & - & 100 & 100 & 77,5 & 89,5 & $\begin{array}{c}95,4 \\
(n=44)\end{array}$ & 91,4 & 100 & - \\
\hline
\end{tabular}

grubu antibiyotikler ampirik tedavi için uygun bulunurken, GSBL oluşturmayan Gram negatif çomaklarda karbapenemlere ek olarak 3. ve 4. kuşak sefalosporinler, aminoglikozidler ve piperasilin+tazobaktamin ampirik tedavi için uygun antibiyotikler olduğu görülmüştür. GSBL pozitif K. pneumoniae için ampirik tedavi seçeneği olmadığı ve bu izolatlarda karbapenem direncinin \%50’ye ulaştığı; GSBL negatif izolatlarda 
3. ve 4. kuşak sefalosporinler, karbapenemler, aminoglikozidler ve siprofloksasinin ampirik tedavi için uygun olduğu bulunmuştur (Tablo 3).

\section{TARTISSMA}

Sepsis, enfeksiyonların neden olduğu, fizyolojik, patolojik ve biyokimyasal anormalliklerin söz konusu olduğu bir sendrom olup dünya çapında önemli bir halk sağlığı sorunudur. Son yapılan tanımlamaya göre sepsis, enfeksiyona düzensiz konak cevabından kaynaklanan hayatı tehdit eden organ işlev bozukluğu olarak; septik şok ise mortaliteyi önemli ölçüde arttıran dolaşımsal ve hücresel/metabolik anomalilerin olduğu sepsisin bir alt grubu olarak tanımlanmaktadır (5). Ciddi klinik durumlarda hastaya en kısa sürede uygun antimikrobiyal tedavinin başlanmasınn yaşamsal önem taşıdığı; septik şok hastalarının \%20'sinde uygun olmayan başlangıç tedavisi uygulandı̆̆ 1 ve bu hastaların sağ kalımında beş kat azalma gözlendiği; uygun antimikrobiyal seçiminin, etkili antimikrobiyalin hızla başlanmasını etkileyen önemli faktörlerden biri olduğu vurgulanmıştır (6). Bu nedenle, sepsis/septik şok hastalarında kümülatif antibiyogram verilerine uygun ampirik tedavi başlanması hayat kurtarıcı olacaktır.

$\mathrm{Bu}$ çalışmada, laboratuvarımıza gönderilen kan kültürlerinden izole edilen Gram pozitif bakterilerden $S$. aureus ve Enterococcus spp, Gram negatif bakterilerden E. coli ve K. pneumoniae için kümülatif antibiyogram raporu hazırlanmıştır. Diğer Enterobacteriales ailesi üyeleri ile nonfermentatif bakterilerden Pseudomonas aeruginosa ve Acinetobacter baumannii suşlarının izolat sayısı <30 olduğu için değerlendirmeye alınmamıştır (Tablo 1). Çoklu ilaç direnci, "üç veya daha fazla antibiyotik grubunun her birinde en az bir ajana dirençli olan mikroorganizmalar" olarak tanımlanmış olup (7), bu çalışmada 3. kuşak sefalosporinlere, aminoglikozidlere ve florokinolonlara dirençli bakteriler çoğul dirençli olarak belirlenmiştir.

Staphylococcus aureus: Staphylococcus aureus (n=94) izolatlarının \% 38,3'ünün metisiline dirençli S. aureus (MRSA) olduğu, bu grupta ampirik tedavi için en uygun antibiyotiklerin vankomisin, teikoplanin ve linezolid olduğu; metisiline duyarlı $S$. aureus

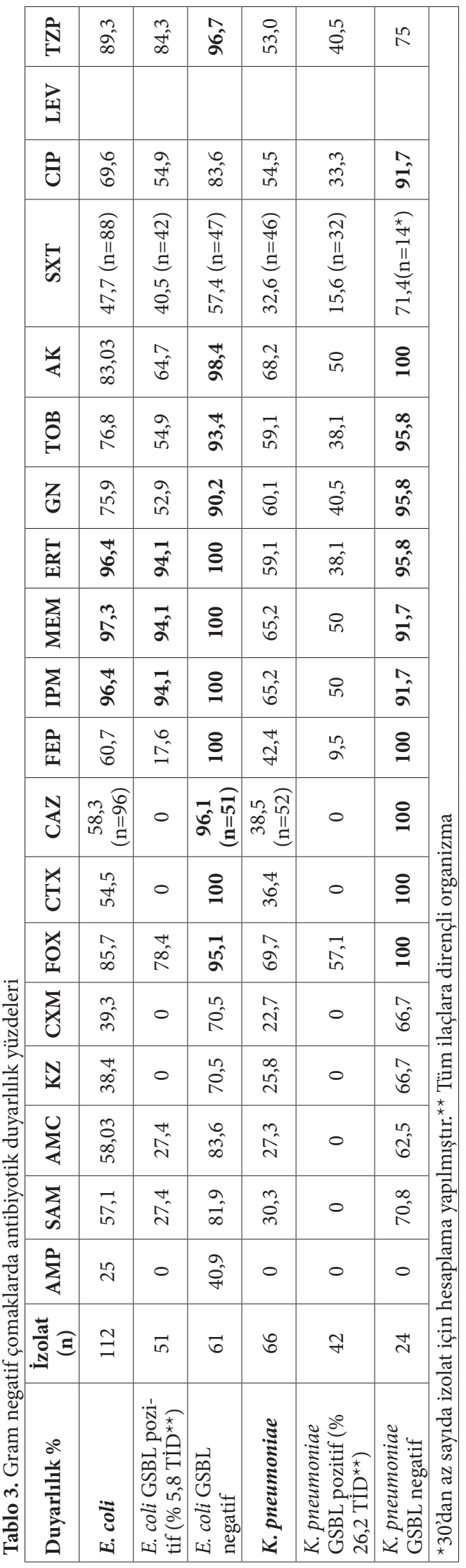


(MSSA) izolatlarında ise bu antibiyotiklere ilave olarak kotrimoksazol ve tetrasiklinin ampirik tedaviye uygun olduğu bulunmuştur. Vankomisine dirençli (VRSA) veya orta dirençli (VISA) S. aureus izolatına rastlanmamıştır (Tablo 2). Ülkemizde yapılan benzer çalışmalara bakıldığında, Şafak ve ark, 2010-2015 yılları arasında 11559 kan kültüründen izole edilen $S$. aureus izolatlarındaki MRSA oranını bizim verimizden çok daha yüksek $(\% 63,6)$ olarak bildirmişlerdir (8). Avrupa antimikrobiyal direnç sürveyans ağ 1 (EARS-NET)'in 2003-2008 yılları arası raporlarına göre Türkiye'deki MRSA oranları sırasıyla $\% 43, \% 40$, \%35, \%36, \%34, \%38 olarak bildirilmiştir (9). Ancak zamanla ülkemizde MRSA oranlarının düşüş gösterdiği bildirilmiş, Ulusal Antibiyotik Direnç Sürveyans Sistemi (UAMDSS) 2016 yılı verilerine göre MRSA oranı \% 23,6 olarak belirlenmiştir $(10,11)$. Yurt dışındaki sürveyans çalışmalarına bakıldığında, EARS-NET 2017 y1llık raporunda, ortalama invazif MRSA oran1 \%16,9 (\%1-44) olarak belirtilmiş ve 2014-2017 yılları arasındaki oranlara göre anlamlı oranda düşüş gösterdiği belirtilmiştir (12). Bizim çalışmamızdaki MRSA oranının $(\% 38,3)$ Türkiye geneli ve Avrupa ülkeleri ortalamasından yüksek olduğu görülmektedir. Buna karşılık, Uzakdoğu ülkelerinden Hindistan'da yapılan direnç sürveyans çalışmasında MRSA izolatlarının oranı ülkemizden ve Avrupa ülkelerinden daha yüksek (\% 40) olarak bulunmuş, ayrıca S. aureus izolatları arasinda \%5,8 VISA ve \%6,9 hVISA izolatı olduğu bildirilmiştir (13).

Enterococcus spp: Kan kültürlerinden izole edilen Gram pozitif bakteriler arasinda Enterococcus spp $(\mathrm{n}=30)$ izolatlarından \%70'inin Enterococcus faecalis olduğu bulunmuştur. E. faecalis izolatlarında ampisilin, glikopeptidler, linezolid ve yüksek düzey gentamisinin ampirik tedaviye uygun olduğu, tüm enterokoklar birlikte değerlendirildiğinde ise sadece glikopeptidler ve linezolidin ampirik tedavi seçeneği olabileceği bulunmuştur. İki (\% 22) Enterococcus faecium ve bir $(\% 4,7)$ E. faecalis izolatının vankomisine dirençli (VRE) olduğu belirlenmiştir. Vankomisine dirençli E. faecium izolatlarında sadece linezolidin ampirik tedaviye uygun olduğu görülmektedir (Tablo 2). Ancak E. faecium ve E. faecalis izolatlarının izolat sayısı $<30$ olduğundan duyarlılık oranlarının istatistiksel olarak düşük \%95 güven aralığına sahip olduğu dikkate alınmalıdır. Örneğin $E$. faecium izolatlarında vankomisinin duyarlılık oranı (\%77) için \%95 güven aralığı \%39-90 ve \%48-95 arasindadır (4). Ülkemizde kan kültüründen izole edilen mikroorganizmalarla yapılan çalışmalara bakıldığında, Er ve ark, E. faecium için \%4,3 oranında vankomisin direnci bildirmişlerdir (14). İstanbul'daki bir devlet hastanesinde yapılan kümülatif antibiyogram çalışmasında Adaleti ve ark, kan kültürlerinden izole edilen E. faecium izolatlarında bizimkinden daha düşük $(\% 9,5)$ VRE oranı bulduklarını bildirmişlerdir (15). Şafak ve ark, 2010-2015 yılları arasında kan kültürlerinden izole edilen toplam 11559 kan izolatının duyarlılık verilerini paylaştıkları araştırmada E. faecalis izolatlarında vankomisin direncine rastlanmadığını, E. faecium izolatlarında bizim verimizden daha düşük (\% 9,4) oranda VRE bulunduğunu bildirmişlerdir (8). Önemli hastane enfeksiyonu etkenleri olduğu bilinen E. faecalis ve E. faecium'un ampisiline dirençli suşlarının tedavisinde kullanılabilecek seçenekler olmaları nedeniyle, bu suşların glikopeptidlere ve yüksek düzey aminoglikozidlere duyarlı olmaları önemlidir. Ülkemizdeki sürveyans sistemi olan UAMDSS 2016 verilerine göre ampisilin, vankomisin ve yüksek düzey aminoglikozid duyarlılık oranları E.faecalis izolatlarında sirasıyla \%94; $\% 98,7$ ve $\% 43$; E. faecium izolatlarında ise $\% 8,4 ; \% 84$ ve $\% 38$ olarak bildirilmiştir (11). Bu çalışmada ise aynı antibiyotikler için duyarlılık oranları E. faecalis izolatlarında sirasıly $\% 90,4 ; \% 95,2$ ve $\% 90,4$; E. faecium izolatlarında ise $\% 11 ; \% 77,7$ ve $\% 66,6$ olarak bulunmuştur. EARS-NET 2017 yıllık raporunda $E$. faecium izolatlarında \%14,9 VRE oranı bildirilmiş, E. faecalis izolatlarında ise VRE oranlarının birçok ülkede çok düşük (\%0-5) olduğu belirtilmiştir. Avrupa ülkelerinde E. faecalis izolatlarında yüksek düzey gentamisin direnci ortalama \%30 iken bizim çalışmamızda \%9,6 oranında bulunması, dikkat çekici bir sonuç olarak karşımıza çıkmaktadır (12). Hastanemizde özellikle kan kültürlerinden VRE izole edilmesi durumunda Hastane Enfeksiyonu Kontrol Komitesi sözlü ve yazılı olarak bilgilendirilmekte ve 
gerekli önlemlerin alınması sağlanmaktadır. Bu uygulamanın VRE oranlarının düşmesine katkıda bulunduğu düşünülmektedir.

Escherichia coli: Kan kültürlerinden izole edilen Gram negatif bakteriler arasında genişlemiş spektrumlu beta laktamaz (GSBL) oluşturan E. coli izolatlarında $(\mathrm{n}=51, \% 45,5)$ sadece karbapenem grubu antibiyotikler ampirik tedavi için uygun bulunurken, GSBL oluşturmayan grupta ( $\mathrm{n}=61, \% 54,5)$ karbapenemlere ek olarak 3. ve 4. kuşak sefalosporinler, aminoglikozidler ve piperasilin+tazobaktamın ampirik tedavi için uygun antibiyotikler olduğu bulunmuştur. GSBL pozitif $E$. coli izolatlarının \%5,8'inin tüm antibiyotiklere dirençli olduğu belirlenmiştir. Yurt içinde yapılan benzer çalışmalar incelendiğinde, Kılınç ve ark, 1646 kan izolatı ile yaptıkları çalışmada, kan kültürlerinden izole edilen $E$. coli izolatlarında seftazidim duyarlılığını \%27, gentamisin duyarlılığını \% 63 ve kinolon duyarlılığını \%36 olarak bulmuşlardır. E.coli izolatlarına ait bu sonuçların, bizim verilerimize göre daha düşük (sırasıyla \%58, \%76, \%70) duyarlılığa sahip olduğu bulunmuştur. Araştırmacilar ayrıca $E$. coli izolatlarında \% 8 oranında imipenem direnci (bu çalışmada \%3,6) olduğunu belirtmişlerdir (16). Şafak ve ark, 2010-2015 yılları arasında kan kültürlerinden izole edilen toplam 11559 kan izolatının duyarlılık verilerini paylaştıkları araştırmada E. coli izolatlarının \%49'unun GSBL oluşturduğunu bildirmiş, gentamisin, amikasin, siprofloksasin ve piperasilin+tazobaktam duyarlılığını sırasıyla $\% 68,6$, $\% 97,5, \% 58,9$ ve $\% 88$ olarak bulmuşlar ve karbapenem direncine rastlamadıklarını belirtmişlerdir (8). Bu sonuçlar arasında gentamisin ve piperasilin+tazobaktam duyarlılığının bizim verilerimizle benzerlik gösterdiği (sırasıyla, \%76, \%89), amikasin duyarlılığımızın düşük (\%83) ve siprofloksasin duyarlılığımızın daha yüksek $(\% 69,6)$ olduğu görülmektedir. Ülkemiz UAMDSS 2016 verilerine göre invazif $E$. coli izolatlarında ampisiline $\% 21,5$, sefotaksime $\% 47,9$, gentamisine $\% 70,7$, amikasine $\% 91,3$, siprofloksasine $\% 45,5$ ve imipeneme \%95; Avrupa Birliği ülkelerinde ise 3.kuşak sefalosporinlere $\% 85,1$; aminoglikozidlere $\% 88,6$; florokinolonlara $\% 74,3$ ve karbapenemlere $\% 92,8$ ortalama duyarlılık oranları verilmiștir $(11,12)$.
Bizim çalışmamızda elde edilen duyarlılık oranları ampisilin için $\% 25$, sefotaksim için $\% 54,5$, gentamisin için \%75,9, amikasin için \%83, siprofloksasin için \%69,6 ve imipenem için \%96,4 olarak bulunmuştur. Sonuçlarımızın Avrupa ülkeleri ortalamasına $(\% 87,8)$ göre daha düşük olan GSBL oranımız $(\% 45,5)$ hariç tutulduğunda, yurt içi ve Avrupa ülkeleri verileri ile uyumlu olduğu görülmektedir. Ülkemizde yapılan bir çalışmada kan kültürlerinden izole edilen $E$. coli izolatları için belirtilen \%57 seftazidim, \%60 sefepim, $\% 95,3$ imipenem, $\% 72$ gentamisin duyarlılıkları hastanemiz verilerine (sırasiyla, $\% 58, \% 60,7, \% 96,4, \% 76$ ) benzemekle beraber, bizim çalışmamızdan (\%69,6 ve $\% 89,3$ ) daha düşük siprofloksasin ve piperasilin+tazobaktam (sırasıyla $\% 52,3$ ve $\% 76,2$ ) ve daha yüksek amikasin $(\% 96,2)$ duyarlılığı bildirmişlerdir. Bu çalışmadaki \%46,7 GSBL pozitif E. coli oranı bizim çalışmamızdaki oran $(\% 45,5)$ ile benzerlik göstermektedir (16). EARS-NET ylllık raporunda, Avrupa'da kan akımı enfeksiyonlarının en yaygın etkeninin bizim sonuçlarımıza ve ülkemizdeki pek çok çalışmaya benzer şekilde E. coli olduğu belirtilmiştir. Ayrıca 2017 yılında Avrupa Birliği ülkelerinde invazif E. coli izolatlarında karbapenem direncinin nadir olduğu, sadece Yunanistan'da \%1-5 oranında iken diğer Avrupa ülkelerinde $<\% 1$ olduğuna dikkat çekilmiştir (12). Çalışmamızdaki E. coli izolatlarında karbapenem direnç oranı \%3,6 ve GSBL pozitif izolatlarda $\% 5,4$ olup Yunanistan'daki direnç oranları ile benzerlik göstermektedir. İlave olarak GSBL pozitif E.coli izolatlarımızın \%5,8'inin tüm antibiyotiklere dirençli olduğu bulunmuştur.

Klebsiella pneumoniae: Çalışmamızda GSBL pozitif $K$. pneumoniae izolatları için ampirik tedavi seçeneği olmadığı bulunmuş, bu izolatların \%28,8'inin çok ilaca dirençli ve \%26,2'sinin tüm antibiyotiklere dirençli olduğu belirlenmiştir. GSBL negatif $K$. pneumoniae izolatlarında ise sefotaksim, sefepim, karbapenemler, gentamisin, tobramisin ve siprofloksasinin ampirik tedavi için uygun olduğu bulunmuştur (Tablo 2). Kılınç ve ark, 1646 kan izolatı ile yaptıkları çalışmada, kan kültürlerinden izole edilen K. pneumoniae izolatlarında \%17 seftazidim, \%48 gentamisin, \%60 kinolon duyarlılı̆̆ bildirmişlerdir. Seftazidim ve 
gentamisin sonuçları bizim sonuçlarımıza (sırasıyla $\% 38,5, \% 60$ ) göre düşük, kinolon duyarlıllğ̆ ise benzer $(\% 54,5)$ olarak bulunmuştur. Araştırmacılar ayrıca K. pneumoniae izolatlarında oldukça düşük $(\% 3,6)$ oranda imipenem direnci (bu çalışmada \%35) olduğunu belirtmişlerdir (16). Şafak ve ark, 2010-2015 yılları arasında kan kültürlerinden izole edilen toplam 11559 kan izolatının duyarlılık verilerini paylaştıkları araştırmada K. pneumoniae izolatlarının \%69,9'unun (bu çalışmada \%63,6) GSBL oluşturduğunu bildirmiş, gentamisin, amikasin, siprofloksasin ve piperasilin+tazobaktam duyarlılığını sırasıyla \%60,5, \%84,5, \%68 ve $\% 48,5$ olarak bulmuşlar ve $\% 41$ karbapenem direncine rastladıklarını belirtmişlerdir (8). Bu sonuçlar arasında gentamisin ve piperasilin+tazobaktam duyarlılığının bizim verilerimizle (sırasıyla, \%60,1 ve \%53) benzerlik gösterdiği, amikasin ve siprofloksasin duyarlılı̆̆ının bizim verilerimize (sırasıyla \%68 ve $\% 54,5$ ) oranla daha düşük olduğu görülmektedir. Ayrıca bizim çalışmamızda nispeten daha düşük $(\% 34,8)$ imipenem direnci bulunmuştur. Coşkun ve ark’nın çalışmasında 621 kan izolatından izole edilen K. pneumoniae izolatlarında seftazidim, imipenem, gentamisin, siprofloksasin ve piperasilin+tazobaktam duyarlilıkları sirasıly $\% 34,2, \% 68,5, \% 56,2, \% 64,4, \% 50$ olarak bildirilmiş, izolatların bizim GSBL oranımıza $(\% 63,6)$ göre daha düşük $(\% 35,6)$ oranda olduğu belirtilmiştir (17). Coşkun ve ark’nın sonuçları bizim verilerimizle amikasin ve siprofloksasin dışında (ikisi de daha duyarlı, \%90,4 ve \%64,4) benzerlik göstermektedir. Ülkemizde UAMDSS 2016 verilerine göre invazif $K$. pneumoniae izolatlarında sefotaksime $\% 31,5$, gentamisine $\% 50,8$, amikasine $\% 70$, siprofloksasine $\% 37,3$ ve karbapenemlere \%60; Avrupa Birliği ülkelerinde ise 3.kuşak sefalosporinlere $\% 68,8$; aminoglikozidlere $\% 75,9$; florokinolonlara $\% 68,5$ ve karbapenemlere $\% 92,8$ ortalama duyarlılık oranları verilmiştir $(11,12)$. Bizim çalışmamızda sefotaksim için duyarlılık oranı \%36,4, gentamisin için \%60,1, amikasin için \%68,2, siprofloksasin için \%54,9 ve imipenem için \%65,2 olarak bulunmuştur. Sonuçlarımızın ülke geneli ile uyumlu, Avrupa ülkeleri ortalamasına göre daha düşük olduğu görülmektedir. Avrupa ülkelerinde GSBL pozitif K. pneumoniae izolatlarının oranı ortalama \%87,8 iken bu çalışmada daha düşük olarak $(\% 63,6)$ bulunmuştur. UAMDSS 2016 verilerinde invazif K. pneumoniae izolatlarının çoklu ilaç direnci \%46 olarak bildirilmiş, bizim çalışmamızda bu oran daha düşük $(\% 28,8)$ olarak bulunmuştur. Çalışmamızda K. pneumoniae izolatlarında gözlenen $\% 28,8$ çoklu ilaç direnci, $\% 34,8$ karbapenem direnci ve $\% 26,2$ oranındaki tüm ilaçlara direncin oldukça önemli olduğu düşünülmektedir. Son yıllarda Gram negatif bakterilerde karbapenemleri de kapsayan yüksek direnç oranları nedeniyle özellikle yoğun bakım ünitelerinde mortalite oranları ile hastanede yatış sürelerinde ve maliyetlerde artışlar ortaya çıkmaktadır (18). Çoğul dirençli ve tüm antibiyotiklere dirençli izolatlarda tek seçenek kolistin gibi görünmektedir. Ancak kolistin molekülünün yapısının büyük olmasindan dolayı agara zayıf difüzyonu nedeniyle duyarlılık deneylerinin sadece sıvı mikrodilüsyon yöntemiyle yapılması gerektiği uluslararası rehberler tarafından bildirilmiştir (19-22). Ayrıca bazı ticari otomatik identifikasyon sistem firmaları da kolistin duyarlılık sonuçlarının güvenilir olmadığını bildirmişlerdir (23). Ancak sıvı mikrodilüsyon yöntemi birçok laboratuvarda olduğu gibi laboratuvarımızda da rutin olarak uygulanamadığından, kümülatif antibiyogram sonuçlarımızda kolistin duyarlılık sonuçları yer almamaktadır. Laboratuvarımızda pratik ve rutin olarak uygulanabilen bir mikrodilüsyon yöntemi olan disk elüsyon yöntemi (24) ile kolistin duyarl1lığ1 saptama için çalışmalara başlanmış bulunmaktadır. Ayrıca çoklu ilaç direnci ve karbapenem direncinin belirlenmesi ve gerekli önlemlerin alınabilmesi için önümüzdeki dönemlerde en az bir yıllık olmak üzere rutin kümülatif antibiyogram raporlar1nın hazırlanarak önceki yılların sonuçlarıyla karşılaştırılması planlanmaktadır.

\section{SONUÇ}

Özellikle GSBL pozitif K. pneumoniae izolatlarında direnç sorununun arttığ 1 ve ampirik tedavi seçeneğinin olmadığı gözlenmiştir. Tüm ilaçlara dirençli izolatlarda kolistin kullanımının uygulamaya konabilmesi için, rutin kullanıma uygun kolistin direnci saptama yöntemleri üzerinde çalışılması ge- 
rekmektedir. Gram pozitif ve Gram negatif bakterilerdeki yüksek direnç oranlarının azaltılabilmesi için, düzenli sürveyans takibinin yapılması ile birlikte Enfeksiyon Kontrol Komitesi çalışmalarının (el y1kama yöntemleri, temas izolasyon önlemleri, sağlik personelinin eğitimi vb) sürdürülmesi gerekmektedir. Ayrıca karbapenemleri de kapsayan çoğul dirençli organizmalar için yeni antibiyotik ve kombinasyonlarının etkinliğini test eden çalışmalara ihtiyaç vardır.

Hakem Değerlendirmesi: Dış bağımsız.

Peer Review: Externally peer-reviewed.

Yazar Katkıları: Çalışma Konsepti/Tasarım- L.Ö.; Veri Toplama- L.Ö.; Veri Analizi/Yorumlama- L.Ö.; Yazı Taslağı- L.Ö.; İçeriğin Eleştirel İncelemesi- L.Ö., Z.A.; Son Onay ve Sorumluluk- L.Ö.; Malzeme ve Teknik Destek- L.Ö. Z.A.; Süpervizyon- L.Ö., Z.A.

Author Contributions: Conception/Design of Study- L.Ö.; Data Acquisition- L.Ö.; Data Analysis/ Interpretation- L.Ö.; Drafting Manuscript- L.Ö.Z.A.; Critical Revision of Manuscript- L.Ö.; Final Approval and Accountability- L.Ö.; Technical or Material Support- L.Ö. Z.A.; Supervision- L.Ö., Z.A.

Çıkar Çatışması: Yazarlar çıkar çatışması beyan etmemişlerdir

Conflict of Interest: Authors declared no conflict of interest.

Finansal Destek: Yazarlar finansal destek beyan etmemişlerdir.

Financial Disclosure: Authors declared no financial support.

Teşekkür: Mikrobiyoloji alanında yetişmemde büyük emeği geçen sayın Prof. Dr. Nezahat GÜRLER’e, verilerin bir kısmının derlenmesinde destek veren Yüksek Lisans öğrencisi Rama Al Hamwi’ye ve tüm laboratuvar çalışanlarımıza teşekkür ederiz.

Acknowledgement: We would like to thank to Prof. Dr. Nezahat Gürler, who contributed greatly to me in the area of medical microbiology, thank to graduate student Rama Al Hamwi, who compiling some data, and all our laboratory staff.

\section{KAYNAKLAR/REFERENCES}

1. Clinical and Laboratory Standards Institute (CLSI). Analysis and Presentation of Cumulative Antimicrobial Susceptibility Test Data; Approved Guideline-Fourth Edition. CLSI document M39-A4. Wayne, PA: Clinical and Laboratory Standards Institute; 2014. Available from: URL: http:/ www.standard@ clsi.org

2. Kohlmann R, Gatermann SG. Analysis and Presentation of Cumulative Antimicrobial Susceptibility Test Data- The Influence of Different Parameters in a Routine Clinical Microbiology Laboratory. PLoS ONE. 2016:11(1):e0147965. doi:10.1371/ journal.pone.0147965

3. Clinical and Laboratory Standards Institute (CLSI). PerformanceStandards for Antimicrobial Susceptibility Testing. 27th ed. CLSI supplement M100. Wayne, PA: Clinical and Laboratory Standards Institute; 2017. Available from: URL: http:/ www.clsi.org

4. Tıbbi Mikrobiyoloji Uzmanları için Antibiyotik Duyarlılık verilerinin analizi ve sunumu rehberi. KLIMUD Kaynak No: 15, Ankara, Mayıs 2019. Available from: URL: https://www.klimud.org/ content/44/rehberler

5. Singer $M$, Deutschman C, Seymour CW, Shankar-Hari M, Annane D, et al. The Third International Consensus Definitions for Sepsis and Septic Shock (Sepsis-3) JAMA. 2016; 315(8): 801-10. doi:10.1001/jama.2016.0287

6. Kumar A, Ellis P, Arabi Y, Roberts D, Light B, Parrillo JE, et al. Initiation of Inappropriate Antimicrobial Therapy Results in a Fivefold Reduction of Survival in Human Septic Shock. CHEST. 2009; 136: 1237-1248. DOI: 10.1378/ chest.09-0087

7. Magiorakos AP, Srinivasan A, Carey RB, Carmeli Y, Falagas ME, Giske CG, Harbarth S, Hindler JF, Kahlmeter G, et al. Multidrug-resistant, extensively drug-resistant and pandrug-resistant bacteria: an international expert proposal for interim standard definitions for acquired resistance. Clin Microbiol Infect 2012;18:268-81.

8. Şafak B, Kılınç O. 2010-2015 yılları arasında kan kültürlerinde üreyen mikroorganizmalar 
ve antibiyotik duyarlılıkları. KLİMİK Dergisi. 2016;29(2):60-4. DOI: 10.5152/kd.2016.15

9. EARSS Annual Report 2008 On-going surveillance of S.pneumoniae, S.aureus, E.coli, E.faecium, E.faecalis, K.pneumoniae, P.aeruginosa Available from: URL: http:// www. ecdc.europa.eu/en/activities/surveillance/ EARS-Net/Documents/2008_EARSS_ Annual_ Report.pdf).

10. Telli M, Okulu Y, Pat Y. Staphylococcus aureus suşlarında metisiline direnç oranındaki değişim: Metisiline direnç azalıyor mu? ANKEM Derg. 2018;32(3):103-8. doi: 10.5222/ankem.2018.1816

11. Ulusal Antibiyotik Direnç Sürveyans Sistemi (UAMDSS) 2016 ylllk raporu. Available from: URL: https://hsgm.saglik.gov.tr/depo/birimler/ Mikrobiyoloji_Referans_Laboratuvarlari_ve_ Biyolojik_Urunler_DB/uamdss/yillik_raporlar/ UAMDSS_2016_Rapor.pdf

12. Surveillance of antimicrobial resistance in Europe. Annual report of the European Antimicrobial Resistance Surveillance Network (EARS-Net) 2017. Available from: URL: https://www.ecdc. europa.eu/sites/portal/files/documents/EARSNet-report-2017-update-jan-2019.pdf

13. Veeraraghavan B, Walia K. Antimicrobial susceptibility profile \& resistance mechanisms of Global Antimicrobial Resistance Surveillance System (GLASS) priority pathogens from India. Indian J Med Res. 2019;149(2): 87-96. DOI: 10.4103/ijmr.IJMR_214_18

14. Er H, Aşık G, Yoldaş Ö, Demir C, Keşli R. Kan kültürlerinde izole edilerek tanımlanan mikroorganizmaların ve antibiyotik direnç oranlarının belirlenmesi. Türk Mikrobiyol Cem Derg. 2015;45(1):48-54. doi:10.5222/ TMCD.2015.048

15. Adaleti R, Kansak N, Aslan M, Aksaray S. Cumulative Antibiogram Test Results of Isolated Microorganisms from Blood Culture Samples at Haydarpaşa Numune Training and Research Hospital. Haydarpaşa Numune Med J. 2019;59(3):HNHJ-43650 [Epub ahead of print]: HNHJ-43650 | DOI: 10.14744/hnhj.2019.43650.

16. Kılınç Ç, Güçkan R, Kahveci M, Kayhan Y,
Pirhan Y, Özalp T. Kan kültürlerinde üreyen Gram negatif izolatların dağılımı ve antibiyotik direnç profilleri. Int $\mathrm{J}$ Basic Clin Med. 2015;3(3):125-30.

17. Coşkun USŞ. Kan kültürlerinde üreyen mikroorganizmalar ve antibiyotik duyarlılıkları. ANKEM Derg. 2018;32(2):45-52. doi: 10.5222/ ankem.2018.045

18. Shorr AF. Review of studies of the impact on Gram-negative bacterial resistance on outcomes in the intensive care unit. Crit Care Med. 2009; 37(4):1463-9. DOI: 10.1097/ CCM.0b013e31819ced02

19. European Committee on Antimicrobial Susceptibility Testing (EUCAST). EUCAST warnings concerning antimicrobial susceptibility testing products or procedures. Available from: URL: http://www.eucast.org/ast_of_bacteria/ warnings/ (Alıntılanma tarihi 19.08.2019)

20. European Committee on Antimicrobial Susceptibility Testing (EUCAST): European Committee on Antimicrobial Susceptibility Testing breakpoint tables for interpretation of MICs and zone diameters, version 8.1. 2018. Available from: URL: http://www.eucast.org/ fileadmin/src/media/PDFs/EUCAST_files/ Breakpoint_tables/v_9.0_Breakpoint_Tables. pdf (Alintılanma tarihi 19.08.2019)

21. Clinical and Laboratory Standards Institute (CLSI). CLSI Subcommittee on Antimicrobial Susceptibility Testing, CLSI AST News Update. 2016:1(2):1-9. https://clsi.org/media/1700/clsi-news-winter-2016. pdf (Alıntilanma tarihi 19.08.2019)

22. European Committee on Antimicrobial Susceptibility Testing. Recommendations for MIC determination of colistin (polymyxin E) as recommended by the joint CLSI-EUCAST Polymyxin Breakpoints Working Group. Vaxjo: EUCAST; 2016. Available from: URL: http://www.eucast.org/fileadmin/src/media/ PDFs/EUCAST_files/General_documents/ Recommendations_for_MIC_determination of_colistin_March_2016.pdf. (Alintılanma tarihi 19.08.2019)

23. Beckton Dickinson. Urgent Field Safety Notice. January 15, 2018. Available from: URL: 
https://laegemiddelstyrelsen.dk/da/udstyr/ sikkerhedsmeddelelser/2018/01/bd-phoenixgram-negative-panels-containing-colistin/ / edia/28798D06546141A9B603E3802DE887AF. ashx (Alıntılanma tarihi 19.08.2019)

24. Simner PJ, Bergman Y, Trejo M, Roberts AA, Marayan R, Tekle T, et al. Two-site evaluation of the colistin broth disk elution test to determine colistin in vitro activity against Gram-negative bacilli. J Clin Microb. 2019;57(2):e0116318. https://doi.org/10.1128/JCM.01163-18. (Alıntılanma tarihi 19.08.2019) 